\title{
Pengembangan Program Pendidikan Anak Usia Dini (PAUD): Peran Pemberdayaan Kesejahteraan Keluarga Dalam Pos PAUD
}

\author{
J.M. Tedjawati \\ Pusat Penelitian Kebijakan dan Inovasi Pendidikan, Balitbang Kemdiknas
}

\begin{abstract}
Abstrak: Tujuan penelitian ini dimaksudkan untuk memperoleh data dan informasi tentang: 1) penyelenggaraan Pos PAUD di lingkungan masyarakat; 2) peran PKK dalam penyelenggaraan Pos PAUD; dan 3) hambatan dan upaya yang dilakukan. Metodologi yang digunakan adalah penelitian kualitataif, dengan lingkup penelitian pelaksanaan program Pos PAUD dan peran PKK di Kabupaten Limapuluh Koto, Kabupaten Gorontalo, dan Kabupaten Gowa. Hasil penelitian menunjukkan bahwa: 1) Pelaksanaan Pos PAUD di tiga kabupaten sudah diselenggarakan berintegrasi dengan kegiatan Posyandu dan BKB; 2) PKK telah bekerjasama dengan Posyandu/Puskesmas dan BKB sesuai dengan harapan Direktorat PAUD dalam menumbuh kembangkan anak usia dini; dan 3) Hambatan yang ditemukan antara lain masih terbatasnya: (a) tenaga kader dan masih rendahnya pendidikan kader, (b) penguasaan ilmu pendidikan para kader, (c) dana untuk pembelian alat permainan (PAUD), (c) ruang untuk bermain, dan (d) evaluasi program PAUD. Upaya yang dilakukan antara lain dengan cara: 1) menggunakan tempat kegiatan secara bergiliran; 2) menggunakan alat bantu mengajar dengan bahan sederhana; dan 3) memberikan kesempatan pada kader PAUD untuk mengikuti pelatihan PAUD.
\end{abstract}

Kata kunci: Program PoS PAUD dan PKK

\begin{abstract}
The purpose of this research is to find informataion and data about: 1) Post implementation of the Post Early Childhood Education (Pos PAUD) in the community environment that includes characteristics of students, teachers, and administrators, the process of activities, evaluation and coaching; 2) PKK role in post implementation of the Post ECE; and 3) Obstacles and problems faced in the implementation of ECE services and attempt what can be done to overcome them. The methodology used is qualitative research, with the scope of this research is the implementation of ECE programs and the role of PKK Limapuluh Koto district, Gorontalo district, and Gowa district. The result showed that: 1) Post implementation of the region have implemented ECE integrated with IHC (Posyandu) and BKB activities; 2 ) the PKK has been carrying out its duties in cooperation with IHC (Posyandu)/ PHC (Puskesmas) and BKB, according to the ECE directorate hopes to help early childhood development, and 3) Obstacles found from the implementation of ECE, among others: (a) Lack of cadres and low educational cadres held; (b) Lack of mastery of the science education of the cadres held; (c) Lack of funds for the purchase of APE; (d) Limitations of space for games; and (e) Evaluation in ECE (PAUD) Programs. To minimalis of the obstaclce has been done by: 1) moving class; 2 ) using symple educational facilities with reuseable material; and 3) giving opportunity to the ECE cader to continue studying or following ECE training programe.
\end{abstract}

Key words: Early childhood education program and education programe for family wealfare (PKK)

\section{Latar Belakang}

Pendidikan anak usia dini (PAUD) adalah jenjang pendidikan sebelum jenjang pendidikan dasar yang merupakan suatu upaya pembinaan yang ditujukan bagi anak sejak lahir sampai dengan usia enam tahun yang dilakukan melalui pemberian rangsangan pendidikan untuk membantu pertumbuhan dan perkembangan jasmani dan rohani agar anak memiliki kesiapan dalam memasuki pendidikan lebih lanjut, yang diselenggarakan pada jalur formal, nonformal, dan informal (Undang-Undang Nomor 20 Tahun 2003).

Pendidikan anak usia dini merupakan salah satu bentuk penyelenggaraan pendidikan yang menitikberatkan pada peletakan dasar ke arah pertumbuhan dan perkembangan fisik (koordinasi motorik halus dan kasar), kecerdasan (daya pikir, daya cipta, kecerdasan emosi, kecerdasan 
spiritual), sosio emosional (sikap dan perilaku serta agama) bahasa dan komunikasi, sesuai dengan keunikan dan tahap-tahap perkembangan yang dilalui oleh anak usia dini. Tujuan penyeleng-garaan PAUD adalah untuk membentuk anak Indonesia yang berkualitas, yaitu anak yang tumbuh dan berkembang sesuai dengan tingkat perkembangannya sehingga memiliki kesiapan yang optimal di dalam memasuki pendidikan dasar serta mengarungi kehidupan di masa dewasa.

Melihat pentingnya pendidikan bagi anak sedini mungkin, maka pemerintah berupaya untuk memenuhi kebutuhan pendidikan anak usia 0-4 tahun dengan berinisiatif untuk mendirikan Direktorat PADU (saat ini disebut Direktorat PAUD) pada tahun 2001. Direktorat ini bertanggung jawab melakukan pembinaan pelayanan untuk anak usia dini yang berumur 0-4 tahun. Direktorat PAUD berada dibawah naungan Direktorat Jenderal Pendidikan Luar Sekolah (sekarang disebut Ditjen PNFI). Direktorat tersebut bertanggungjawab dalam pembinaan PAUD pada jalur pendidikan nonformal dan informal.

Layanan PAUD non formal dilaksanakan untuk anak-anak yang berusia di bawah 4 tahun yakni berupa kelompok bermain (KB), tempat penitian anak (TPA), dan Satuan PAUD Sejenis. Sedangkan layanan PAUD jalur formal diperuntukkan bagi anak usia 4-6 tahun berupa TK A dan B (Peraturan Pemerintah Nomor 27 Tahun 1990). Namun berdasarkan data, awal tahun 2009 menunjukkan bahwa dari sekitar 29,8 juta anak, yang terlayani pendidikan baru sekitar 15,1 juta anak (Petunjuk Pelaksanaan Rintisan PAUD Tahun 2010). Khususnya melalui jalur pendidikan nonformal dibawah Direktorat PAUD hanya terlayani sekitar 3 juta anak. Pada PAUD formal pada tahun 2000 hanya dapat mampu menampung 12,65 persen dari anak usia 4-6 tahun atau 1.6 juta anak. Berdasarkan kondisi tersebut pemerintah telah menetapkan rencana 5 tahun ke depan Angka Partisipasi Kasar (APK) PAUD diharapkan mencapai 21,3 juta $(72,6 \%)$ (Direktorat PAUD: Leaflet Direktorat PAUD, 2009). Secara bertahap harapan untuk mencapai jumlah APK-PAUD nonformal adalah 11,6 juta $(38,5 \%)$ tahun 2010, 12,85 juta $(42,43 \%)$ tahun 2011,14 juta $(46,2 \%)$ tahun 2012 , 15,05 juta $(49,7 \%)$ tahun 2014 , dan 16,1 juta $(52,9 \%)$ tahun 2015.
Salah satu tujuan dan sasaran strategis Renstra Depdiknas 2010-2014 berdasarkan jenjang layanan pendidikan dan sistem tata kelola yang diperlukan untuk menghasilkan layanan prima pendidikan adalah tersedia dan terjangkaunya layanan PAUD berkualitas dengan memperhatikan inklusifitas di semua provinsi, kabupaten dan kota. Sasaran strategis untuk mencapai tujuan strategis tersebut antara lain: (i) Kualifikasi untuk pendidik PAUD formal (TK/TKLB) diharapkan $85 \%$ berpendidikan menimal S1/D4 dan $85 \%$ bersertifikat, sedangkan untuk Pendidik PAUD non formal diharapkan telah dilatih sekurangkurangnya 55\% pada tahun 2014; (ii) Pada tahun 2014 diharapkan seluruh satuan pendidikan anak usia dini formal menerapkan system pembelajaran yang membangun karakter (kejujuran, kepedulian, tanggung jawab dan toleransi) dan menyenangkan bagi anak.

Pos PAUD merupakan salah satu bentuk pelayanan dari program Satuan PAUD Sejenis yang berintegrasi dengan kegiatan Posyandu dan Bina Keluarga Balita (BKB). Pos PAUD ini diperuntukkan bagi masyarakat yang belum siap mengikutsertakan anaknya dalam layanan PAUD yang lebih intensif, baik karena alasan kerepotan mengantar, ekonomi, maupun masih rendahnya kesadaran orangtuanya. Pos PAUD ini memberikan layanan rangsangan pendidikan bagi anak usia dini dan orangtuanya melalui pemberian wahana bermain dan contoh-contohnya.

Permasalahan yang timbul adalah seberapa jauh layanan Pos PAUD yang diberikan kepada masyarakat saat ini bermanfaat bagi orangtua anak usia dini: 1) bagaimanakah penyelenggaraan layanan Pos PAUD di masyarakat?; 2) bagaimanakah peran Pemberdayaan Kesejahteraan Keluarga dalam layanan Pos PAUD?; dan 3) bagaimanakah hambatan dan permasalahan yang dihadapi dalam penyelenggaraan Pos PAUD dan upaya apa yang dapat dilakukan untuk mengatasinya?

Tujuan dari penelitian ini dimaksudkan untuk memperoleh data dan informasi tentang kelayakan program Pos PAUD yang melayani masyarakat. Secara khusus tujuan penelitian ini adalah untuk memperoleh data dan informasi tentang: 1) penyelenggaraan Pos PAUD di lingkungan masyarakat yang meliputi karakteristik 
peserta didik, pendidik, dan pengelola, proses kegiatan, evaluasi dan pembinaan; 2) peran PKK dalam penyelenggaraan Pos PAUD; dan 3) hambatan dalam penerapan layanan model PAUD sejenis dan upaya mengurangi hambatan yang telah dilakukan.

\section{Kajian Literatur}

\section{Pengembangan Anak Usia Dini Holistik Integratif}

Pengembangan Anak Usia Dini (AUD) holistik integratif bertujuan untuk: 1) terpenuhinya kebutuhan esensial anak usia dini secara utuh meliputi kesehatan dan gizi, pendidikan, dan pengasuhan sesuai segmentasi umur; 2) terlindunginya anak dari perlakuan yang salah, baik pada tataran keluarga maupun lingkungan; 3) terselenggaranya pelayanan anak usia dini secara terintegrasi dan selaras antar lembaga pelayanan terkait, sesuai kondisi wilayah; dan 4) terwujudnya komitmen seluruh unsur terkait dalam penyelenggaraan pengembangan AUD (Bappenas, 2008).

Prinsip-prinsip pengembangan anak usia dini holistik integratifyaitu: 1) Pelayanan yang holistic, yaitu pengasuhan secara dini yang dilakukan di rumah, pendidikan bagi orang tua dan anggota keluarga serta pengasuh pengganti dalam pengasuhan anak. pelayanan kesehatan dan gizi, penyediaan sanitas yang baik dan sehat, perawatan dan pendidikan usia dini di pusat-pusat pelayanan pendidikan, serta perlindungan hukum terhadap perlakuan salah, termasuk eksploitasi dari kekerasan terhadap anak; 2) Pelayanan yang berkesinambungan. Sistem pelayanan yang terkoordinasi dan terintegrasi secara baik yang memberikan pelayanan secara berkelanjutan sejak janin sampai usia 6 tahun; 3) Pelayanan yang tidak diskriminatif. Pelayanan-pelayanan hendaknya memberikan perlakuan yang adil kepada seluruh anak usia dini baik laki-laki maupun perempuan, termasuk memenuhi kebutuhan anak yaitu piatu, anak-anak dengan kebutuhan khusus, termasuk anak-anak cacat, berkebutuhanan khusus, dan anak-anak yang berada dalam wilayah konflik, masyarakat miskin, pedesaan, kawasan terpencil dan kepualauan, dan tempat pengungsian; 4) Perluasan distribusi pelayanan antar kelompok masyarakat dilakukan dengan menerapkan prinsip aksesibilitas, ketersediaan, keterjangkauan ekonomi, dan penerimaan sosiokultural; 5) Partisipasi masyarakat. Masyarakat harus dilibatkan dalam tahap perencanaan, pelaksanaan, pemantauan dan evaluasi program pengembangan anak usia dini holistic-integratif, sehingga rasa memiliki terhadap program dari masyarakat menjadi lebih kuat; 6) Berbasis budaya yang konstruktif. Program pelayanan anak usia dini hendaknya mempertimbangkan budaya local dan global yang positif dan sesuai dengan kebutuhan tumbuh kembang anak secara optimal; dan 7) Good governance, yang mencakup transparansi, akuntabilitas, partisipatif, serta efisiensi dan efektivitas pemanfaatan sumber daya yang ada. Dengan demikian, diharapkan seluruh potensi anak usia dini dapat tergali dan berkembang secara optimal.

Arah kebijakan pengembangan anak usia dini holistic-integrative mencakup: 1) Peningkatan akses, pemerataan, dan kelengkapan jenis pelayanan pengembangan anak usia dini. Kebijakan ini diarahkan untuk menjamin agar kebutuhan anak usia dini terhadap semua jenis pelayanan yang utuh dan lengkap (holistic) dapat terpenuhi, baik secara kuantitas maupun sebaran layanan, sehingga anak usia dini mempunyai kesempatan yang lebih besar untuk berkembang secara optimal; 2) Peningkatan kualitas penyelenggaraan pelayanan pengembangan anak usia dini. Kebijakan ini diarahkan untuk menjamin agar anak usia dini mempunyai kesempatan lebih besar untuk dapat berkembang secara optimal dengan tersedianya pelayanan yang utuh dan lengkap (holistic), berkualitas, baik dari segi kapasitas, kualitas SDM, kelengkapan materi, sarana, dan prasarana; 3) Peningkatan koordinasi dan kerja sama lintas sector, serta kemitraan antar institusi pemerintah, lembaga penyelenggara layanan, dan organisasi terkait, baik local, nasional, maupun internasional. Kebijakan ini diarahkan untuk: (a) mengembangkan penyediaan layanan pengembangan anak usia dini secara berkelanjutan dengan pengaturan mekanisme koordinasi, tugas pokok dan fungsi, serta bentuk kemitraan para pemangku kepentingan; (b) meningkatkan efisiensi layanan pengembangan anak usia dini dengan mem- 
bangun system yang integrative melalui koordinasi lintas sector dan antar tingkatan pemerintah; dan (c) meningkatkan pengintegrasian kerjasama pengembangan anak usia dini pada semua tahapan pembangunan, mulai dari perencanaan, pelaksanaan, pemantauan, hingga evaluasi secara berkesinambungan; 4) Penguatan kelembagaan keluarga dan kelembagaan pelayanan dasar hukum, serta pelibatan masyarakat termasuk dunia usaha dan media massa dalam penyelenggaraan pelayanan pengembangan anak usia dini. Kebijakan ini diarahkan untuk meningkatkan penguatan kelembagaan-kelembagaan tersebut dengan

orangtuanya (Direktorat PAUD, 2008).

Tujuan program Pos PAUD adalah: 1) memberikan model layanan PAUD yang dapat menjangkau masyarakat luas hingga ke pelosok pedesaan; 2) memberikan wahana bermain yang mendidik bagi anak-anak usia dini yang tidak terlayani PAUD lainnya; dan 3) memberikan contoh kepada orangtua dan keluarga tentang cara-cara pemberian rangsangan pendidikan kepada anak untuk dilanjutkan di rumah.

Berbagai faktor yang mendukung terselenggaranya Pos PAUD dapat dilihat pada Gambar 1.

\section{Pemberdayaan Kesejahteraan Keluarga}

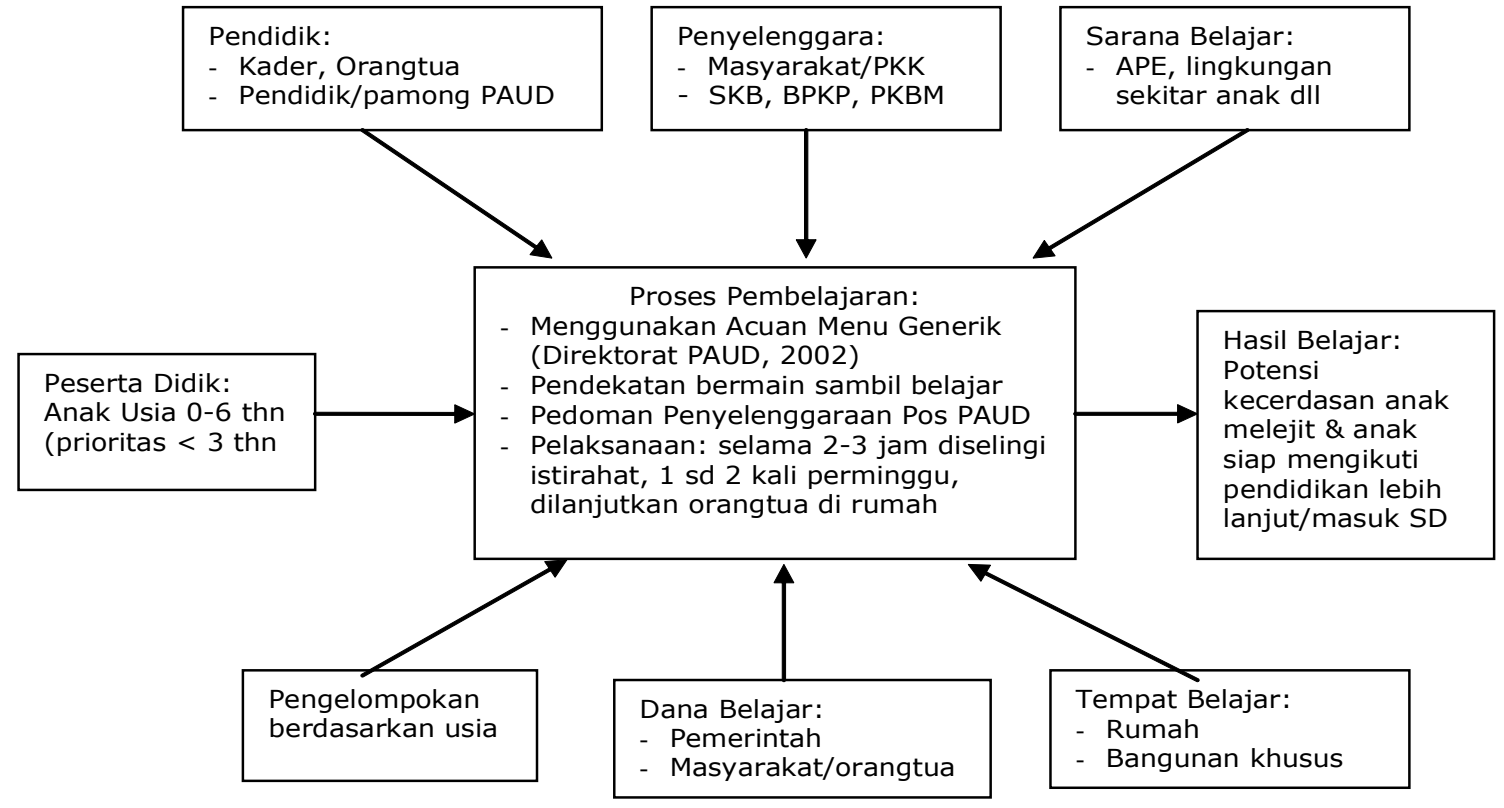

Gambar 1. Penyelenggaraan Program Satuan PAUD Sejenis, Khususnya Program PAUD Terintegrasi Posyandu/BKB (Pos PAUD)

sistem yang integratif dan upaya penyusunan aspek legitimasi seperti penyusunan rancangan Undangundang, Peraturan Presiden, dan pedoman umum serta meningkatkan peran serta masyarakat, termasuk dunia usaha dan media massa.

\section{Program Pos PAUD}

Pos PAUD merupakan bentuk layanan PAUD yang diintegrasikan dengan program Bina Keluarga Balita (BKB) dan Pos Pelayanan Terpadu (Posyandu). Pos PAUD diperuntukkan bagi masyarakat yang belum siap mengikutsertakan anaknya dalam layanan PAUD yang lebih intensif, baik karena alasan kerepotan mengantar, ekonomi, maupun masih rendahnya kesadaran
Dalam TAP MPR Nomor: IV/MPR/1983 tentang GBHN telah ditetapkan bahwa PKK (Pembinaan Kesejahteraan Keluarga) adalah salah satu wahana untuk meningkatkan peranan wanita dalan upaya menyejahterakan keluarga. Gerakan PKK merupakan Gerakan Nasional dalam pembangunan masyarakat yang tumbuh dari bawah, yang pengelolaannya dari, oleh dan untuk masyarakat. Pemberdayaan Keluarga meliputi segala upaya Bimbingan, Pembinaan dan Pemberdayaan agar keluarga dapat hidup sejahtera, maju dan mandiri (http://www. surabaya.go.id/eng/pdf/pkk/Seputar\%20PKK. pdf). Tim Penggerak PKK adalah Mitra Kerja Pemerintah dan Organisasi Kemasyarakatan, 
yang berfungsi sebagai fasilitator, perencana, pelaksana, pengendali dan penggerak pada masing-masing jenjang demi terlaksananya program PKK. Tim Penggerak PKK adalah warga masyarakat, baik laki-laki maupun perempuan, perorangan, bersifat sukarela, tidak mewakili organisasi, golongan, parpol., lembaga, atau instansi, dan berfungsi sebagai perencana, pelaksana, dan pengendali gerakan PKK.

Tujuan Gerakan PKK adalah memberdayakan keluarga untuk meningkatkan kesejahteraan lahir bathin menuju terwujudnya keluarga yang: 1) Beriman dan bertaqwa kepada Tuhan YME; 2) Berakhlak mulia dan berbudi luhur; 3) Sehat sejahtera; 4) Maju mandiri; 5) Kesetaraan dan keadilan gender; dan 6) Serta kesadaran hukum dan lingkungan. Sasaran Gerakan PKK adalah Seluruh Anggota Keluarga yang masih perlu ditingkatkan dan dikembangkan kemampuan dan kepribadiannya dalam bidang: 1) Mental spiritual, meliputi sikap dan perilaku sebagai insan hamba Tuhan, anggota masyarakat dan warga negara yang dinamis serta bermanfaat, berdasarkan Pancasila dan UUD 1945; dan 2) Fisik material, meliputi pangan, sandang, papan, kesehatan, kesempatan kerja yang layak serta lingkungan hidup yang sehat dan lestari melalui peningkatan pendidikan, pengetahuan dan keterampilan.

Dalam rangka pencapaian tujuan, Gerakan PKK mempunyai Visi dan Misi. Visi PKK adalah Terwujudnya keluarga yang beriman dan bertakwa kepada Tuhan YME, berakhlak mulia dan berbudi luhur, sehat, sejahtera, maju dan mandiri, kesetaraan dan keadilan gender serta kesadaran hukum dan lingkungan. Misi PKK meliputi: 1) Meningkatkan mental spiritual, perilaku hidup dengan jelan menghayati dan mengamalkan Pancasila serta meningkatkan pelaksanaan hak dan kewajiban sesuai dengan Hak Asasi Manusia (HAM), demokrasi, meningkatkan kesetiakawanan sosial dan kegotongroyongan serta pembentukan watak bangsa yang mantap dan seimbang; 2) Meningkatkan pendidikan dan ketrampilan yang diperlukan dalam upaya mencerdaskan kehidupan bangsa serta meningkatkan pendapatan keluarga; 3) Meningkatkan kualitas dan kuantitas pangan keluarga, serta upaya peningkatan pemanfaatan pekarngan melalui Halaman Asri Teratur Indah dan Nyaman (HATINYA) PKK, sandang dan penataan rumah sehat; 4) Meningkatkan derajat kesehatan fisik dan mental, kelestarian lingkungan hidup serta membiasakan hidup berencana untuk kehidupannya dan perencanaan ekonomi keluarga serta membiasa-kan menabung; dan 5) Meningkatkan pengelolaan gerakan PKK baik kegiatan, pengorganisasian maupun pelaksanaan program-programnya, yang disesuaikan dengan situasi dan kondisi masyarakat setempat sesuai ketentuan yang berlaku (http://www.surabaya.go.id/ eng/pdf/pkk/ Seputar\%20PKK.pdf).

Gerakan PKK dikelola oleh Tim Penggerak PKK yang dibentuk di Pusat, Propinsi, Kabupaten/Kota, Kecamatan, Desa/Kelurahan. Hubungan kerja antara Tim Penggerak PKK Pusat dengan Daerah adalah bersifat Konsultatif dan Koordinatif dengan tetap memperhatikan hubungan hierarkis. Untuk mendekatkan jangkauan pemberdayaan kepada keluarga-keluarga secara langsung, dibentuk kelompok-kelompok PKK RW, RT dan kelompok Dasa Wisma (http://www.suarakarya-online.com/ news.html?id=115587)

Kriteria keanggotaan Tim Penggerak PKK yaitu: 1) Bertakwa kepada Tuhan Yang Maha Esa, berakhlak mulia dan berbudi pekerti luhur; 2) Dapat membaca dan menulis; 3) Relawan; 4) Peduli terhadap upaya pemberdayaan dan kesejahteraan keluarga; 5) Bersifat perorangan dan tidak mewakili suatu organisasi, golongan, partai politik, lembaga atau sektor; 6) Mempunyai waktu yang cukup; dan 7) Memiliki kemauan dan etos kerja yang tinggi.

Untuk mendukung pelaksanaan programprogram gerakan PKK, dibentuk Dewan Penyantun Tim Penggerak PKK baik di Pusat maupun di Propinsi, Kabupaten/Kota, Kecamatan dan Desa/Kelurahan. Diketuai oleh Mendagri, Gubernur, Bupati/Walikota, Camat dan Kepala Desa/Lurah. Anggota: Pimpinan Instansi/Lembaga yang membidangi tugas-tugas Pemberdayaan dan Kesejahteraan Keluarga, para tokoh/pemuka masyarakat, petugas lapangan Instansi dan Lembaga Kemasyarakatan yang ditetapkan dengan keputusan Dewan Penyantun.

Ada sepuluh program PKK yaitu Penghayatan dan Pengamalan Pancasila, gotong royong, pendidikan, keterampilan, pengembangan kehidupan berkoperasi, pangan dan sandang, perumahan dan tata laksana rumah tangga, 
kesehatan, kelestarian lingkungan hidup, dan perencanaan sehat. Pelaksanaan kesepuluh program PKK tersebut dijabarkan dalam empat Pokja yaitu: 1) Pokja I menangani program Penghayatan dan Pengamalan Pancasila, gotong royong; 2) Pokja II menangani program pendidikan dan keterampilan, serta pengembangan kehidupan berkoperasi; 3) Pokja III menangani program pangan, sandang, perumahan dan tata laksana rumah tangga; dan 4) Pokja IV menangani program kesehatan, kelestarian lingkungan hidup, dan perencanaan sehat.

\section{Metodologi}

Pendekatan yang digunakan dalam penelitian ini adalah pendekatan kualitatif. Lingkup penelitian ini adalah pelaksanaan program Pos PAUD dan peran PKK dalam menunjang penyelenggaraan Pos PAUD. Sampel penelitian adalah kabupaten Limapuluh Koto, kabupaten Gorontalo, dan kabupaten Gowa.

Teknik pengumpulan data dalam penelitian ini menggunakan wawancara mendalam, dan observasi. Instrumen yang digunakan adalah pedoman wawancara dan pedoman observasi. Teknik analisis data yang digunakan adalah kualitatif dengan menyusun hasil wawancara dan observasi, kemudian data tersebut dicocokkan dengan program Pos PAUD yang dijadikan pedoman dalam pembelajaran PAUD.

\section{Temuan Penelitian dan Pembahasan}

Temuan dari penelitian ini ditinjau dari penyelenggaraan layanan Pos PAUD, peran PKK dalam penyelenggaraan Pos PAUD, dan hambatan serta upaya yang ditemukan dalam penyelenggaraan Pos PAUD.

\section{Penyelenggaraan Pos PAUD}

Pos PAUD diselenggarakan oleh masyarakat dengan bekerjasama dengan pemerintah daerah di tingkat kecamatan/desa. Karena Pos PAUD merupakan upaya layanan pendidikan bagi anak usia dini yang berintegrasi dengan layanan kesehatan, gizi, dan pengasuhan anak, maka penyelenggaraan Pos PAUD selalu melibatkan kegiatan Posyandu yang diselenggarakan setiap bulan. Kegiatan integrasi ini sesuai dengan harapan yang saat dikembangkan pemerintah yaitu pengembangan anak usia dini yang holistik integratif.

Di kabupaten Gorontalo sudah dikeluarkan Peraturan Daerah (Perda) Nomor 1 Tahun 2009 tentang Penyelenggaraan Pendidikan, pada Bab VII Pasal 32 tentang Pendidikan Anak Usia Dini. Perda tersebut lebih memperjelas pentingnya pendidikan anak usia dini. Selain itu Perda tersebut ditindaklanjuti dengan dikeluarkannya Peraturan Bupati Gorontalo Nomor 33 Tahun 2009 tentang Pendidikan Anak Usia Dini. Dengan diberlakukannya Perda dan peraturan tersebut maka setiap desa harus didirikan Pos PAUD untuk menampung anak usia dini untuk dapat mengikuti pembelajaran sambil bermain.

\section{Kader Pos PAUD}

Pada umumnya kader Pos PAUD berasal dari tenaga sukarelawan dan kader Posyandu maupun PKK. Sebagian besar Kader Pos PAUD berpendidikan SLTA, dan hanya 2 orang berpendidikan S1 (dari jumlah 15 orang Kader). Bahkan ada seorang Kader yang berpendidikan lulusan Sekolah Guru Tuna Netra, yang ternyata sangat bermanfaat ketika menghadapi anak inklusif.

Pengalaman mengajar dari Kader Pos PAUD rata-rata baru 2-3 tahun dan hanya $10 \%$ di antaranya sudah pernah mengajar di PAUD (diantaranya di Kelompok Bermain) selama 5 tahun. Sedangkan pelatihan yang berkaitan dengan PAUD terutama pendekatan pembelajaran Beyond Centre and Circle Time (BCCT) baru diikuti oleh sebagian kecil Kader.

Pelaksanaan tugas kader sesuai Panduan Pos PAUD telah dilakukan. Tugas kader dilaksanakan sesuai dengan pengelompokkan usia anak Pos PAUD, di mana pengelompokkan usia anak tersebut berbeda-beda rentang usianya, seperti 2-3 tahun, 3-4 tahun, 5-6 tahun. Ada juga yang dikelompokkan 0-3 tahun, 4-6 tahun. Bahkan ada yang belum dikelompokkan (hanya ada 1 kelompok saja) yakni 3-6 tahun.

Dalam melaksanakan tugasnya, umumnya para kader telah melaksanakan sesuai dengan ketentuan dalam Panduan Pos PAUD. Namun ada beberapa tugas yang belum dilakukan oleh para kader dalam kelompok usia anak apapun yakni mencatat perkembangan anak, daftar hadir memiliki kartu deteksi dini tumbuh kembang anak (DDTK) dan melakukan deteksi dini dengan 
menggunakan kartu tersebut.

Pandangan kader mengenai tingkat perkembangan anak yang baik adalah anak yang dapat berkembang sesuai usia pertumbuhannya, sosialisasi anak yang baik; setiap bulannya anak tersebut mengalami kenaikan berat badan, daya tanggapnya tajam, daya ingin tahunya besar; anak berkembang sesuai dengan umur anak dan waktu kapan mereka harus dapat bicara maupun berhitung; serta perkembangan jiwa anak dan emosional yang sesuai dengan usia anak.

Menurut kader pentingnya bermain bagi tumbuh kembang anak dapat meningkatkan dalam: 1) melatih kreatifitas, kedewasaan, kecerdasan dan sosialisasi anak; 2) belajar dari segala perkembangan seperti melatih daya pikir, ide dan melatih motorik kasar, membina hidup bersosial/berbagi; 3) tumbuh kembang anak adalah untuk menstimulus otak anak dan sebagai media pembelajaran; dan 4) perkembangan jiwa anak, emosionalisasi, sosialisasi, dan agama.

Pada pertemuan di Pos PAUD, biasanya Kader Posyandu memberikan penjelasan yang berkaitan dengan 1) penimbangan berat badan anak dan imunisasi; 2) penyuluhan kesehatan anak dan gizi; 3) pemberian makanan tambahan; dan 4) laporan dan pencatatan di KMS.

Pada umumnya Kader dari Pendidikan mengajarkan anak membaca doa dan bernyanyi, sedangkan orangtua diberi penyuluhan tentang doa, berhitung (bagi anak 4-5 tahun) dan bertepuk tangan sambil bernyanyi (bagi anak 02 tahun). Namun demikian masih banyak Kader yang hanya mendampingi anak dalam bermain tanpa memberi penjelasan dari contoh-contoh yang harus dipelajari oleh orangtua.

Dari kenyataan lapangan yang diperoleh ditemukan fakta bahwa perbandingan jumlah Kader dengan jumlah murid timpang atau tidak sesuai, rata-rata perbandingannya adalah $1: 20$, hal ini menunjukkan bahwa di daerah terdapat kekurangan tenaga pengajar POS PAUD yang memungkinkan adanya kurang maksimalnya perkembangan anak. Kurangnya jumlah tenaga pengajar juga dilatar belakangi oleh kurangnya dana yang dimiliki oleh POS PAUD.

Pada umumnya Kader Pos PAUD mengetahui jenis kegiatan bermain yang harus dilakukan di Kelompok Pos PAUD. Sebagai contoh untuk anak usia 0-2 tahun diberikan main sensorimotor yaitu mainan yang merangsang gerakan motorik halus dan kasar. Sedangkan anak usia 2-4 tahun diberikan main sensorimotor dan main peran.

\section{Pengelola Pos PAUD}

Seluruh pengelola Pos PAUD berasal dari warga desa setempat. Mereka ikut terlibat dalam pembelajaran sebagai kader pendamping karena mereka berkeinginan untuk mentransfer ilmu kepada masyarakat. Secara garis besar struktur pengelola terdiri dari Ketua, Sekretaris, dan Bendahara dan juga merangkap jabatan sebagai kader POS PAUD. Pengelola tersebut dipilih melalui musyawarah di lingkungan masyarakat sekitar lokasi.

Kepengurusan Pos PAUD telah berjalan sesuai dengan aturan yang ditentukan Pos PAUD masing-masing yaitu ada yang 2 (dua) tahun lama kepengurusannya tetapi ada juga yang 3 (tiga) tahun. Selain itu penunjukan sebagai pembina dilakukan oleh Lurah setempat dengan dukungan dari tokoh-tokoh masyarakat, ataupun oleh pihak Yayasan dimana Pos PAUD bernaung.

\section{Kegiatan Pos PAUD}

Kegiatan Pos PAUD diselenggarakan beraneka ragam pelaksanaannya antara lain: 1) Kegiatan diselenggarakan hanya 2 kali sebulan di Posyandu (di Balai Desa) dan rumah Kader yaitu (a) pada saat penimbangan anak (kegiatan Posyandu, hari rabu minggu kedua); dan (b) pengarahan pendidikan di rumah Kader (hari rabu minggu ketiga) untuk anak usia 0-2 tahun. Bagi anak usia 3-4 tahun dapat datang di Kelompok Bermain yang letaknya tidak jauh dari lokasi balai desa dan biasanya 2 atau 3 kali seminggu, terserah anaknya; 2) Kegiatan diselenggarakan dua kali sebulan yaitu satu dilakuakan di Posyandu (Balai Desa) dan satu lagi dilakukan di Kelompok Bermain. Di Posyandu dilakukan pada saat penimbangan anak dan di Kelompok Bermain yang ada di sekitar balai desa; 3) Kegiatan diselenggarakan di Posyandu (di Balai Desa) dengan waktu tiga kali sebulan (setiap 10 hari sekali). Pada waktu pertemuan anak diajari suatu permainan dan dipinjami alat permaian tersebut. Sementara itu, 
orangtuanya diberi arahan cara memainkan dan nilai apa saja yang ada dalam permaian tersebut. Setelah 10 hari anak dan orangtua datang kembali ke Balai Desa dan mempraktekan/memperlihatkan cara bermain yang telah dipelajari di rumah, serta mengembalikan alat permaian untuk nantinya digantikan dengan alat permainan lain yang akan dibawa ke rumah.

Pada umumnya kegiatan Pos PAUD dilakukan pada pagi hari. Namun ada juga Pos PAUD yang dilakukan pada sore hari. Iuran dari orangtua untuk penyelenggaraan Pos PAUD tidak ada ketentuan jumlah yang harus dibayarkan oleh para orangtua. Hal ini dikarenakan orangtua anak usia dini tersebut berasal dari keluarga "kurang mampu" sehingga penyelenggaraan Pos PAUD hanya mengandalkan kepada "kerja sosial" dari para Kader. Demikian juga dengan insentif bagi kader rata-rata diterima Rp 300.000,- per bulan. Insentif tersebut diperoleh dari bantuan dana APBN. Insentif yang diterima oleh kader ini memang rendah sekali, karena pada umumnya kader Pos PAUD bekerja dengan sukarela.

\section{Peran PKK dalam penyelenggaraan Pos PAUD}

Pimpinan Pusat PKK mengharapkan para kader PKK harus dan tetap terus giat melaksanakan tugas dan fungsinya yang utama yaitu berusaha memberdayakan dan mensejahterakan keluarga. Oleh karenanya, Pokja II sesuai dengan tugas pokoknya yaitu menangani pendidikan dan kesehatan, meliputi penyuluhan pendidikan anak usia dini, mengusahakan alat permaianan edukatif, kursus menjahit, rias pengantin dan lainnya, mengelola taman bacaan atau sudut baca, dan membudayakan minat baca keluarga dan masyarat, membentuk kelompok Bina Keluarga Balita (BKB) dan melaksanakan kegiatan BKB. Disadari pula bahwa untuk melejitkan potensi tumbuh kembang otak, setiap anak membutuhkan asupan gizi, perlindungan kesehatan, pengasuhan dan rangsangan pendidikan sesuai dengan perkembangan anak.

Selama ini Kementerian Pendidikan Nasional melalui Direktorat PAUD menggandeng organisasi PKK untuk mengembangkan pendidikan anak usia dini http://www.suarakarya-online.com/news. html?id=115587. Pertimbangannya, organisasi tersebut memiliki keanggotaan hingga tingkat akar rumput (grass root) dan yang terpenting anggotanya adalah para ibu yang dekat dengan keseharian anak. Keterlibatan anggota PKK dalam program PAUD bisa berupa penyelenggaraan PAUD di tingkat RT/RW dengan memanfaatkan fasilitas yang ada di sekitar, seperti kantor RW, kelurahan atau pelataran masjid. Oleh karenanya secara faktual dan terbukti di beberapa daerah, kelahiran PAUD juga dibidani PKK ataupun Posyandu. Karena selama ini diluar rumah peran tumbuh kembang anak melalui pemantauan gizi dan kesehatan anak dilakukan di Posyandu atau Puskesmas. Selain itu menurut Pengurus PKK, PAUD sebenarnya bukan sesuatu yang baru bagi anggota PKK. Karena sebelumnya pihaknya sudah dilibatkan pada kegiatan serupa yang dikembang-kan Kantor BKKBN melalui program Keluarga Bina Balita (BKB). Hanya dalam bidang pendidikan, Pos PAUD mengajarkan untuk membaca doa dan bernyanyi, sedangkan orangtua diberi penyuluhan tentang doa, berhitung (bagi anak 4-5 tahun) dan bertepuk tangan sambil bernyanyi (bagi anak 0-2 tahun).

Para Kader PKK umumnya bersedia menjadi kader Pos PAUD, dengan alasan untuk memajukan dan meningkatkan tumbuh kembang anak di desanya. Selain itu di daerahnya sendiri belum adanya sarjana PAUD atau yang relevan yang bersedia jadi kader PAUD. Selama ini sebelum lahirnya Pos PAUD, kader PKK dan Posyandu yang selalu memperhatikan tumbuh kembang anak melalui penyuluhan pengasuhan anak, gizi, dan kesehatan.

Pada umumnya penyelenggaraan PAUD didasarkan pada tugas "sukarela" karena kurangnya dana yang menunjang dalam program PAUD. Walau demikian pemerintah sudah berusaha untuk memberikan insentif bagi kader PAUD, namun insentif ini masih sangat kurang. Kader PAUD hanya menerima uang insentif sekitar Rp $300.000,-$, namun banyak juga kader PAUD yang tidak menerima uang insentif tersebut.

\section{Hambatan dan upaya dalam penyelenggaraan Pos PAUD}

Hambatan yang umumnya ditemukan dalam penyelengaraan program Pos PAUD adalah kaderkader Posyandu, kader BKB, kader PKK, dan kader Pendidik belum menguasai ilmu kependidikan dan tidak percaya diri, keterbatasan tenaga kader yang terlatih dan berpendidikan hanya minimal SMU, 
keterbatasan dana sehingga untuk mengembangkan permainan masih terbatas, sarana termasuk alat permainan edukatif kurang memadai karena terbentur dana, sumber daya manusia sebagai kader masih kurang, keterbatas-an tempat/arena anak untuk bermain dan belajar, dan evaluasi belum dapat dilaksanakan oleh kader dan penyelenggara.

Upaya yang telah dilakukan guna mengatasi hambatan tesebut adalah mensiati tempat/kelas dengan cara memakai ruang tersebut secara bergiliran, mensiati ketebatasan alat dengan improvisasi alat atau bahan yang mudah didapat dari lingkungan sekitar atau Alat Permainan Edukatif (APE) menggunakan daur ulang, mensiati kekurangan alat dengan meminjam pada Kelompok Bermain yang berada tidak jauh dari penyelenggaraan Pos PAUD, memberikan kesempatan pada kader PAUD untuk mengikuti pelatihan atau belajar di penyelenggara PAUD yang dijadikan contoh atau lebih maju dalam penyelenggaraan PAUD, memberikan motivasi dan semangat kepada para kader.

\section{Simpulan dan Saran}

\section{Simpulan}

Pelaksanaan Pos PAUD di daerah sudah diselenggarakan berintegrasi dengan kegiatan Posyandu dan BKB. Walau pendidikan Kader masih terbatas hanya lulusan SMA, namun mereka telah berusaha melakukan tugas sesuai Pedoman kecuali mencatat perkembangan anak, daftar hadir, memiliki kartu deteksi dini tumbuh kembang anak (DDTK) dan melakukan deteksi dini dengan menggunakan kartu tersebut. Demikian juga dengan pengelola yang seringkali juga merangkap sebagai kader dengan tujuan untuk mentransfer ilmunya kepada masyarakat dan telah melakukan tugas sesuai Pedoman.

Peran PKK dalam PAUD sangat dominan di daerah. Ini sesuai dengan tugas PKK yaitu berusaha memberdayakan dan mensejahterakan keluarga termasuk pengembangan anak usia dini ditinjau dari asupan gizi, perlindungan kesehatan, pengasuhan dan rangsangan pendidikan sesuai dengan tumbuh kembang anak. Selain itu selama ini dalam menjalankan tugasnya PKK telah bekerjasama dengan Posyandu/Puskesmas dan BKB. Hal ini yang sangat diharapkan Kemendiknas dalam mengembangkan program PAUD di daerah yaitu bekerjasama dengan PKK untuk per-kembangan anak usia dini. Ditambah pula penyelenggaraan program Pos PAUD selama ini juga didasarkan pada tugas "sukarela" walau pemerintah sudah berusaha memberi insentif bagi sebagian kader PAUD.

Hambatan yang ditemukan dalam penyelenggaraan PAUD antara lain kurangnya tenaga kader dan masih rendahnya pendidikan yang dimiliki kader, kurangnya penguasaan ilmu pendidikan yang dimiliki para kader, kurangnya dana untuk pembelian APE, keterbatasan ruang untuk permainan, dan evaluasi dalam program PAUD. Upaya yang telah dilakukan oleh penyelenggara PAUD antara lain membuat APE dari daur ulang yang ada di sekitarnya atau meminjam APE dari kelompok bermain, para kader berusaha menambah pengetahuan dengan belajar pada kader yang lebih pandai.

\section{Saran}

Mengacu pada simpulan penelitian, maka disarankan agar: 1) Perlu pemberian diklat secara rutin kepada Kader yang dapat dilakukan oleh dinas pendidikan atau pengelola sendiri atau HIMPAUDI terutama dalam hal penyuluhan mendidik anak sesuai dengan usia dan perkembangan anak; 2) Ada penguasaan pembuatan APE yang berasal dari daur ulang atau yang ada di lingkungan dan mudah diperoleh, yang harus dikuasai oleh Kader. Untuk itu perlu diadakan diklat atau penyediaan buku yang berkaitan dengan pembuatan APE; 3) Ada pertemuan secara rutin bagi para Kader baik Kader dari pendidikan, Posyandu maupun BKB untuk membahas materi berkaitan dengan perkembangan anak, kesehatan, dan gizi, terutama yang berkaitan dengan pendidikan pembelajaran anak usia dini melaui permainan. Dengan adanya pertemuan tersebut, para Kader dapat bertukar pikiran/ilmu di antara mereka sehingga mereka dapat membimbing anak usia dini sesuai dengan usia dan perkembangan anak; dan 4) Ada penggalangan dana bagi penyelenggaraan Pos PAUD yang dapat diperoleh melalui bantuan masyarakat setempat melalui Pengurus Desa, iuran warga di desanya.

\section{Pustaka Acuan}

Bappenas, 2008. Studi Kebijakan: Pengembangan Anak Usia Dini Yang Holistik dan Terintegrasi. Jakarta: Bappenas.

Direktorat PAUD, 2008. Pedoman Teknis 
Penyelenggaraan Pos PAUD. Jakarta: Depdiknas.

Direktorat PAUD, 2010. Petunjuk Pelaksanaan Rintisan PAUD 2010. Jakarta: Depdiknas.

Direktorat Jenderal Pendidikan Nonformal dan Informal, 2009. Mengenal Pendidikan Anak Usia Dini di Indonesia. Leaflet Direktorat PAUD.

Kementerian Pendidikan Nasional (2010). Rencana Strategis Kementerian Pendidikan Nasional Tahun 2010-2014 (Draft), Jakarta: Kementerian Pendidikan Nasional.

Peraturan Daerah (Perda) Kabupaten Gorontalo Nomor 1 Tahun 2009 tentang Penyelenggaraan Pendidikan.

Peraturan Pemerintah Nomor 27 tahun 1990 tentang Pendidikan Prasekolah.

Peraturan Bupati Gorontalo Nomor 33 Tahun 2009 tentang Pendidikan Anak Usia Dini.

Peraturan Mendiknas Nomor 58 tahun 2009 tentang Standar Pendidikan Anak Usia Dini.

Pendidikan Nasional Menggandeng PKK Kembangkan PAUD, 19 Juli 2005 http://www.suarakaryaonline.com/news.html?id=115587.

Pengertian Gerakan PKK dalam http://www.surabaya.go.id/ eng/pdf/pkk/ Seputar\%20PKK.pdf

TAP MPR Nomor : IV/MPR/1983 tentang Garis Besar Haluan Negara.

Undang-Undang No. 20 Tahun 2003 tentang Sistem Pendidikan Nasional. 